\title{
Problems and challenges of full-time and school-based VET in Germany
}

\section{Thomas Deissinger}

\section{Introduction}

In the area of VET (vocational education and training), there is growing pressure that VET should not only produce portable skills for the labour market, but also enable individuals to progress to higher education (HE). The functionality of VET qualifications and underlying pathways is therefore embedded within a more general debate on flexibility and permeability within education systems. This includes the general function of different pathways (e.g. workplace learning in the dual system vs. full-time vocational education in schools or colleges) but also the notion of 'hybrid qualifications' (HQ) and, with it, 'functional diversification' of VET. HQ, in political and pedagogical terms, are obviously rather underrepresented in the German VET context, while Anglo-Saxon countries, but also Switzerland or Austria, either place stronger emphasis on 'progression routes', or have deliberately undertaken reforms in this area. In Germany, full-time VET serves a number of functions within the VET system. This variety will be outlined and two essential characteristics of full-time courses in this country will be identified: (1) the fact that they only partly have a skill formation function with respect to occupational labour markets against the preponderance of the dual apprenticeship system, and (2) that their contribution to permeability mostly consists in the provision of the same qualifications as those in general secondary education (e.g. Abitur - the university entrance qualification), which also means that they do not deliver vocationally based HQs in the first place. Against this background, it seems that we also need a specific theoretical understanding of what 'full-time' and/ or 'school-based' means, especially in relation to the dual system and the typical 'occupational' orientation within the German VET system.

\section{The location of full-time VET within the German education system}

\section{General overview}

Looking at VET as a 'system' requires differentiation between 'structure' and 'function' of the respective system architecture in a given country. Although 
it seems problematic to use the notion of a well-organised entity for existing social systems in general, or for education systems in particular (including the non-systemic character of the so-called dual system in Germany), it makes sense to stick to the term 'system' for pragmatic reasons. System theory helps us to understand the relationship between sub-systems in a given society, their interaction, their specific working principles and the way in which they reveal a 'difference' between themselves and their environment (Luhmann and Schorr, 1979). When looking at VET as a system, the various levels on which it works become relevant. VET systems are not solely depictable on the 'macro level' (normally associated with institutions, structural features and responsibilities of the various stakeholders), but need be understood in their specific pedagogical and/or didactical quality. Kell (2006) differentiates between four system levels, i.e. 'macro', 'exo', 'meso' and 'microsystem'. In the case of VET, 'macro' and 'micro' stand for the structural framework and the learning processes, while 'exo' indicates that there are strong determining systems 'around' the VET systems, in particular the employment system and the (higher) education system. Finally, 'meso' refers to the institutions in which vocational learning processes takes place, e.g. schools or companies or partnerships of these two (Kell, 2006, p. 460). It is evident that the links and the interdependences between these system levels give a VET system a distinctive shape and quality in relation to other educational sub-systems.

Young people not going to university in Germany traditionally undertake apprenticeships in the dual system which is characterised by the notion of 'recognised qualifications' based on the Vocational Training Act (Greinert, 1994; Deissinger, 1996). The dual system is a major pathway into skilled employment and also a crucial element of workforce development for many companies. Being virtually an apprenticeship system its core element is qualifying young people in an 'occupation' (Deissinger, 1998, 2010; Deissinger and Breuing, 2014), although it also opens up formalised progression to further training (such as the 'Meister'). There are a number of historical and cultural reasons for calling it the 'centrepiece of vocational education and training in the Federal Republic' (Raggatt, 1988, p. 166), which can still be seen when looking at the statistics of VET. In 2015, some 1.4 million young people were receiving initial training in the dual system, while some 1.1 million attended to a vocational school outside the apprenticeship system (Statistisches Bundesamt, 2017a, p. 26; Statistisches Bundesamt, 2017b, p. 18).

Besides state regulation the dual system also contains the sphere of 'public responsibility', with trade unions, employer organisations and chambers acting as stakeholders and, in the case of chambers, supervising and examining bodies. This principle of self-government goes back to the ancient guild system. As it never wholly disappeared in the process of industrialisation, it has basically survived as a cultural pattern. The Craft Act of 1897 contributed to the foundations of the corporatist framework still typical of the dual system (Deissinger, 1996) as it led to a revival of the guild system and stipulated chambers as selfgoverning organisations for the craft sector. Therefore, in Germany, there is a 
'long-standing and highly regulated participation of business/industry in training' in the initial training sector, which is certainly 'an outstanding feature of the German system' (Noah and Eckstein, 1988, p. 62). At the same time in schools, this system architecture differs fundamentally from full-time VET: firstly, companies are not involved systematically in VET; and, secondly, governmental regulation is mostly located on the federal state level, due to the German constitution which forbids involvement of the federal government in educational affairs.

One of the indicators of a gradual weakening of the position of company-based training within Germany's educational architecture is the rise of young people entering special transition programmes (Übergangssystem) or opting for vocational courses in full-time VET which traditionally have been a more or less ancillary system to the dual system when it comes to skill formation (Deissinger, 2007; Dobischat et al., 2009; Seeber and Michaelis, 2015). Both in comparison with entries into $\mathrm{HE}$ and with participants in non-company-based formal training, the dual system has always been considered to be the main destination for school leavers. However, this situation has changed, since more students in Germany now enter HE than new apprentices in the dual system or students in full-time VET. In 2016, some 480,000 apprentices embarked on their training in the dual system while some 511,000 young people began their studies in HE (BMBF, 2017, p. 45).

The following chart (see Figure 11.1) shows the positioning of full-time VET within the education system in Germany.

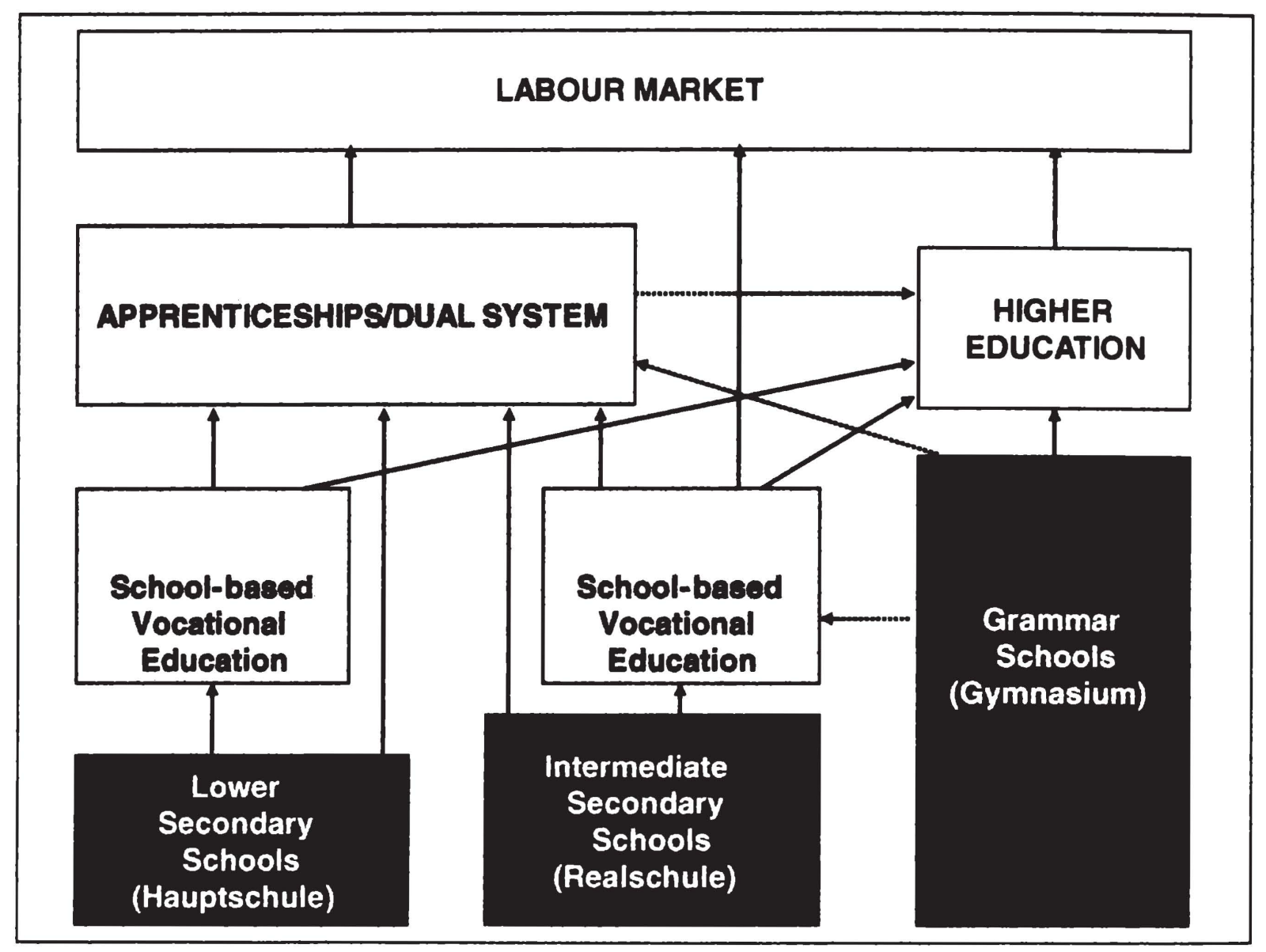

Figure II.I The German education system's own chart, for a comparable source see e.g. MKJS Baden-Württemberg, 2014, p. $6 f$. 
Progression routes in the chart indicate three major modes of 'student traffic' (Harris et al., 2005):

- Moving from general secondary education to VET

- Moving within the VET system between full-time VET and the dual system

- Moving from the VET system to higher education.

The dotted lines indicate that these are non-traditional traffic routes: this means that only a small number of school leavers from the grammar schools find their way straight to the apprenticeship system, while this way is quite common from the highest level of the full-time VET sector (vocational high school), which provides the full university entrance qualification. Also, moving from the apprenticeship system into $\mathrm{HE}$ is only possible once graduates of dual training already possess a university entrance qualification - although they can embark on studies at a university of applied sciences with the so-called 'Fachhochschulreife' (which is mainly achieved in the VET sector, not in general education). The continuous lines stand for the conventional pathways, which include direct entry into apprenticeships from lower and intermediate general education, as well as progressing from higher secondary VET in schools into $\mathrm{HE}$. All these pathways nowadays have come under pressure with academic drift (Deissinger and Ott, 2016; Deissinger and Gonon, 2016), i.e. the aspirations of young people and their parents to enter a grammar school after year four (i.e. at the age of ten). In Germany, academisation can be observed as early as in the 1960s. Between 1965 and 1990, the share of school leavers with an Abitur rose from some 7 per cent to 27 per cent (Jacob and Solga, 2015, p. 163). The recent academic drift particularly materialises in the concept of the Gemeinschaftsschule in the federal state of Baden-Württemberg (a kind of comprehensive secondary school merging the lower and the intermediate secondary school) where objectives such as permeability (Durchlässigkeit) and equality of opportunities (Chancengleichheit) are the underlying pedagogical and, more to the point, political motives (Bohl and Meissner, 2013). Also, transferring from primary school to secondary school is much more open than in former decades and 'meritocratic' attitudes of parents have become stronger, which explains recent educational reforms which have been unfavourable to the lower secondary schools (Neugebauer, 2010).

We will discuss this later in this paper, as it is closely associated with the high level of diversity within the full-time VET system. This latter certainly is complicated by the fact that the federal states in Germany regulate school-based VET so that one may assume that the country has an even more diversified structure than what has developed in institutional terms due to a kind of double function of VET as it is perceived in the German context. This means that VET is not exclusively awarding labour market relevant qualifications, but also serves educational aspirations of young people who want to proceed to a higher level in the educational hierarchy (Deissinger et al., 2006). 


\section{Classification of full-time vocational schools and school-based troining outside the dual system}

Against this background, we can point out what may be called the functional diversity of full-time VET (Zabeck, 1985; Deissinger et al., 2006; Feller, 2002, 2004; Dobischat et al, 2009; Seeber and Michaelis, 2015). It is possible to distinguish six sub-types of vacational schools/courses in Germany (with only the first constituting the dual apprenticeship system):

I Part-ime vocational schools which provide underpinning theoretical knowledge and general education for apprentices in the dual system (Berufsschulen)

II Full-cime schools that qualify young people in so-called 'school occupations', mainly 'assistant occupations', based on federal state law (Berufsfachschulen, Berufskollegs) - These types of schools account for $6.7 \%$ of entrants to school-based VET in Germany and an additional $10.2 \%$ who obtain a HQ (BiBB, 2017 ,p. 197)

III Full-time schools that provide skill formation for young people via so-called 'school occupations' based on the Vocational Training Act (Berufsfachschulen) - these types of schools account for just $2.1 \%$ of entrants to schoolbased VET in Germany (BiBB, 2017 , p. 197)

IV School-based formalised training leading to a nationally recognised qualification in the health and human services sector (hospital nurses, nurses for the elderly, physiotherapists) (Schulen des Gesundheitswesens) - this is the largest category of school-based training and accounts for $81 \%$ of VET entrants in the school-based system (BiBB, 2017 , p. 197)

V Full-time courses within the 'transition system' (mostly aiming at vocational preparation and/or bridging general education and apprenticeships) (Berufsvorbereitungsjahr and similar courses) ${ }^{1}$

VI Full-time vocational schools that lead to educational qualifications (lower secondary school standard, intermediate secondary school standard, university of applied sciences entry qualification, general university entry qualification, e.g. in Wirtschaftsgymnasien) - these schools/courses partly provide for the academic aspirations of young people, though they also may lead into an apprenticeship.

The categories indicate that 'full-time VET' in Germany is a term which only partly describes the character of these educational institutions correctly. In fact, it is necessary to distinguish two major types overarching the above-mentioned categories. Only a proportion of courses (namely categories II, III and IV) work as full-time VET in the sense that the objective of attendance is actually training and with it achieving a labour market relevant qualification. I therefore suggest to name category VI 'full-time VET in a narrow sense', since courses here neither contain substantial practical periods nor the participation of companies as young people reach out for higher school qualifications. In contrast, 'full-time 
VET in a wider sense' means (categories II, III and IV) that schools play a dominant role in the skill formation process, or that learning exclusively takes place in the classroom and in workshops or workplaces in the school building, or that it is physically and institutionally linked up with a VET school (e.g. a hospital).

Apart from these school-based courses, the transition system (category V) which 'offers young people an opportunity to improve their individual chances of gaining training' (Federal Ministry of Education and Research, 2017, p. 60) is a heterogeneous catch-all for those striving to become an apprentice, but also for school leavers who are uncertain about their futures and drop-outs from school. Here, migrants and young men make up the majority of participants. Another feature of the transition system is that there is school-based provision, company-based internships (called 'entry qualifications') and vocational preparation and orientation courses offered by private training providers. The number of young people entering this sub-system of VET has risen between 2015 and 2016, also due to the widening of programmes for young refugees and asylum seekers. It is especially the school-based 'vocational preparation year' or 'pre-vocational year' that has become more important recently. However, as a category, it is not really an unequivocal part of full-time VET (Federal Ministry of Education and Research, 2017, p. 60; for more details on the transition system, see also Schmidt, 2011).

The health sector (category IV) with its non-academic health and care occupations (Zöller, 2012) is a particularly interesting example of the second major type. The reason is that most of these occupations formally neither belong to the dual system (although the training is dual/alternating) nor to the 'normal' pathways of progression in full-time vocational schools leading to educational qualifications (e.g. the Abitur). These schools are only partly a sub-category of the full-time VET system, under the auspices of the federal states, due to the fact that training in these occupations is not exclusively school-based, as the participation of organisations, e.g. hospitals, is required - which means this sub-system resembles, at least partly, the learning configuration of the dual apprenticeship system. However, in the official statistics, health, health-related and human services occupations are not always different from category II. This corresponds with the fact that roughly half of the student population of these institutions get their training in 50 occupations under federal state law, including, e.g. nurse assistants or child care specialists/nursery nurses, while only 17 occupations are based on nationally uniform regulations and curricula. Training times stretch from 12 to 36 months (the latter mainly for the nationally regulated health occupations such as nurse or physiotherapist) (BiBB, 2017, p. 200). In fact, health, health-related and human services occupations are distributed in various ways among three sub-sectors of schoolbased VET (Bonse-Rohmann, 2015; Zöller, 2012; Feller, 2004): full-time VET in Berufsfachschulen (mostly based on federal state law); special health schools (normally attached to hospitals); and well-established health-related occupations (health provision) trained in the dual system (Zöller, 2012, p. 7). In the 
latter category, we find occupations such as the medical assistant (to medical doctors), which is one of the most frequently selected occupations among young women (BMBF, 2017, p. 34).

Categories II, III and IV represent the essential sub-systems in full-time VET outside the dual system. This is especially the case for social and child care, as well as for beauticians, which represent a sub-category under the auspices of the federal states and the respective school laws (Friese, 2017, pp. 35). However, it is sometimes quite difficult to relate numbers of students entering the various courses to these different streams of VET, especially when we look at full-time VET based on federal state law and the transition system, since there are intersections between the two, e.g. the vocational full-time school building upon the lower secondary school certificate and leading young people to an intermediate school qualification (Berufsfachschule). This category of school also is the one with the most heterogeneous course structure (Feller, 2002; Feller, 2004).

The three following charts/tables depict the rough shares and the underlying streams of (mostly) full-time VET in Germany under the heading 'Berufsfachschulen'. The common feature of those among these schools that deliver portable qualifications for employment is that they either are not offered in the dual system or belong to a specific 'family' of occupations, such as health, health-related and human services occupations. Besides, as already mentioned, there are some occupations, called 'assistant qualifications' which traditionally are trained in vocational full-time schools. Another sub-group consists of occupations that can also be trained in the dual system, e.g. beautician (Feller, 2004, p. 49); see Figure 11.2.

In terms of numbers, Tables $11.1,11.2$ and 11.3 illustrate the most frequently trained occupations in full-time VET, either based on national or federal state law. One can conclude from these figures that there is quite a large segment of school-based occupations outside the dual system, while the sector of health, health-related and human services occupations is a kind of 'dual system' outside the apprenticeship system, which is treated as a separate sphere of VET (because it is school-based but not full-time) and which we will touch on but not discuss in more detail in this chapter. In contrast to these occupations those based on the Vocational Training Act or the Craft Regulation Act (normally training occupations in the dual system) are quite negligible (with falling numbers in the past few years and due to a more accessible training market in the apprenticeship system). ${ }^{2}$ This latter fact once again underlines the overall importance of the dual system, providing training in nearly all of the state recognised training occupations, and reveals that full-time VET in many of its sub-categories has a compensatory (transitional) or complementary function in relation to apprenticeships (Deissinger, 2010). It needs to be recalled that the apprenticeship system with its 330 training occupations takes up nearly 500,000 young people annually which accounts for some 1.4 million young people in training (BMBF, 2017, p. 45). 


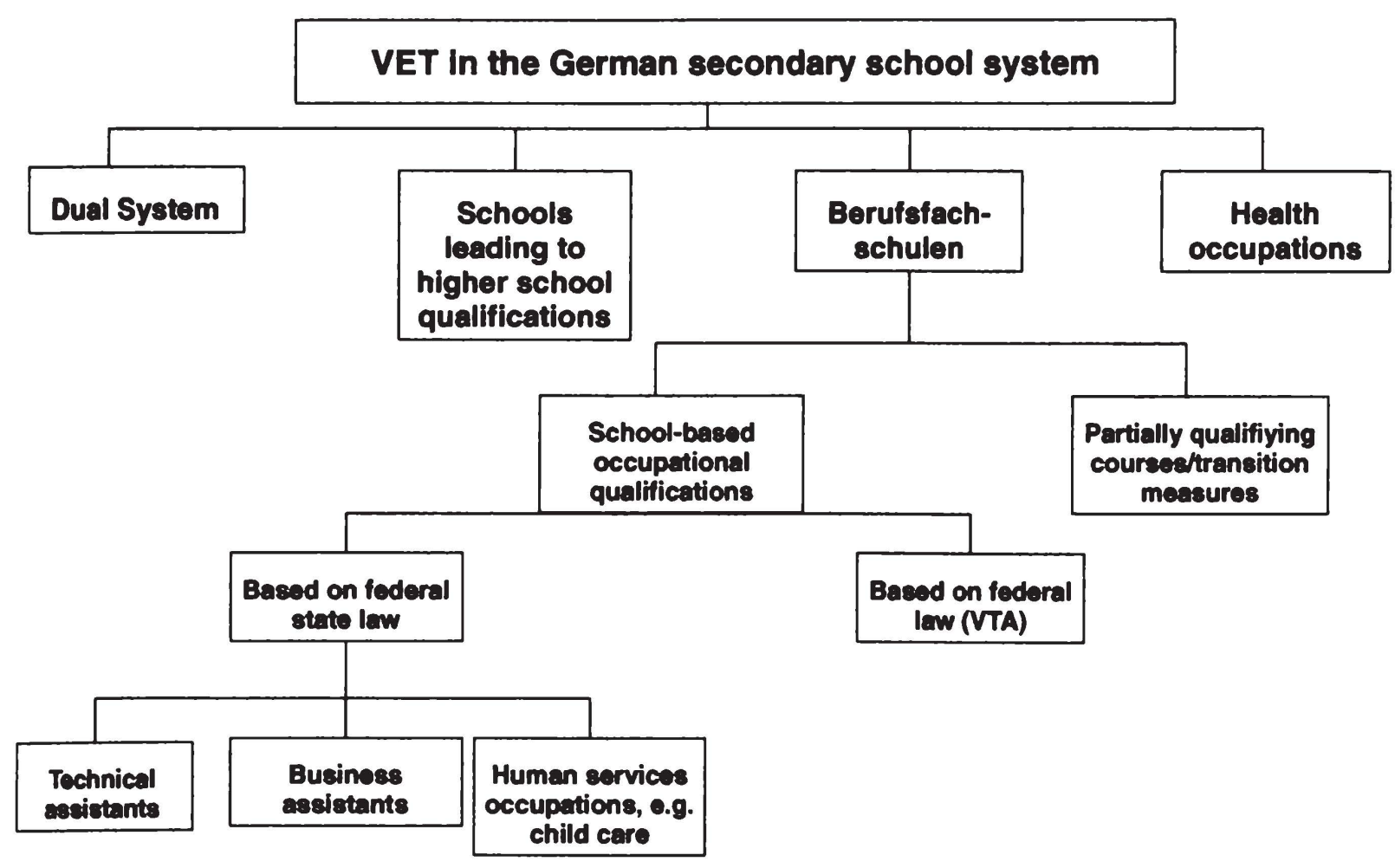

Figure II.2 Full-time VET and school-based VET in 'Berufsfachschulen' own chart based on Feller, 2002, p. 140

It needs to be added that the meaning of 'federal law' stretches beyond the scope of the Vocational Training Act or the Craft Regulation Act (the joiner, e.g., may be trained full-time though numbers are very low), but - in the case of health occupations - is associated with the Health Care Act (Krankenpflegegesetz) which requires a specific pattern of training of normally three years in the case of nurses (now called Gesundheits-und Krankenpfleger/in). ${ }^{3}$ Another notable feature is that those school occupations (e.g. business assistant) that are not health-related or which do not offer alternative training through the dual system under the same denomination (e.g. office management assistant) are comparatively weak in terms of numbers. It can also be seen that many school occupations are dominated by female students. Generally, the share of VET taking place in schools in relation to the dual apprenticeship system has been stable since 2005 . In 2016 , it roughly stands at 30 per cent against 70 per cent but differs enormously between individual federal states: in most of the East German states, there is more occupational training in schools than on average countrywide. On the other hand, states such as Bavaria or Hamburg have lower shares, which generally spread between 18.8 per cent in Bremen to 43 per cent in Berlin. The health sector is the largest sub-category of school-based occupational training, reaching from roughly 70 per cent in Rheinland-Pfalz up to nearly 99 per cent of school-based vocational trainees in the Saarland (BiBB, 2017, p. 198). 
Table II.I Major sectors with school-based entrants in 2016

\begin{tabular}{lcl}
\hline & $\begin{array}{l}\text { Entrants toVET } \\
\text { programmes }\end{array}$ & $\begin{array}{l}\text { Percentage of students } \\
\text { who are femole }\end{array}$ \\
\hline $\begin{array}{l}\text { School occupations based on federal state } \\
\text { law without health sector }\end{array}$ & 14,463 & 55.6 \\
$\begin{array}{l}\text { School occupations based on federal law } \\
\text { Health, health-related and human services } \\
\text { occupations (federal and federal state law)* }\end{array}$ & $\begin{array}{l}17,448 \\
\text { School-based occupations leading to a }\end{array}$ & 21,897 \\
$\begin{array}{l}\text { hybrid qualification } \\
\text { Total }\end{array}$ & 215,288 & 77.9 \\
\hline
\end{tabular}

Source: based on data from BIBB (2017)

Table / I.2 Most important occupations in school-basedVET in 'Berufsfachschulen' 2015/16 based on federal law (including some of the major health-related occupations)

\begin{tabular}{lrl}
\hline Occupation & Entrants in 2015/16 & $\begin{array}{l}\text { Percentage of students } \\
\text { who are female }\end{array}$ \\
\hline Elderly care worker* & 23,612 & 74.8 \\
Nurse (m/f)* & 22,892 & 79.2 \\
Physiotherapist & 8,346 & 60.6 \\
Pharmaceutical assistant & 3,756 & 89.5 \\
Ergotherapist & 3,610 & 88.8 \\
Beautician** & 1,106 & 99.7 \\
Office management & 926 & 55.1 \\
assistant** & &
\end{tabular}

NB: * health occupation, not strictly full-time, but basically dual/** also trained in the dual system

Source: based on data from BIBB (2017)

Table / I.3 Most important occupations in school-based VET in 'Berufsfachschulen' 2015/16 based on federal state law (including some of the major health-related occupations)

Occupation

Entrants in 2015/16

Percentage of students who are female

Nursery nurse*

24,750

80.9

Social care assistant

17,055

78.1

Social pedagogical assistant

12,723

83.7

Elderly care assistant*

7,718

77.9

Information engineering assistant

3,548

5.5

Nurse assistant*

3,486

77.1

NB: * health or related occupations not strictly full-time, but basically dual

Source: based on data from BIBB (2017) 


\section{The marginal relevance of hybrid qualifications}

Category VI among the VET schools in Germany leads us to take a closer look at educational qualifications within the VET system and also HQs. Schools in this category are quite strong in some federal states and focus on progression as far as HE. In 2015/16, the number of students in vocational schools in Germany (including apprentices in the dual system) stood at some 2.5 million, among which Berufsfachschulen in general accounted for the largest proportion besides the part-time vocational school (some 17.3\%). Apart from the occupational courses in some of these schools, full-time VET (in a narrow sense) here functions as a catalyst for the 'pathway of the second chance' for young people without higher school certificates, which often means helping school leavers to enter the dual system more smoothly after attending a vocational course at a Berufsfachschule or a Berufskolleg. It is of considerable interest that nearly all certificates opening access to universities of applied science (Fachhochschulreife) are achieved in full-time vocational schools. Also, in 2016, more than 56,000 Abitur certificates (full university entrance qualifications) were obtained in vocational full-time schools nationwide (which accounts for some 16 per cent of all certificates of this kind) (Statistisches Bundesamt, 2017c, p. 3ff.). In this context, schools such as Berufsoberschulen (leading to a general university entrance qualification), Fachoberschulen and Berufskollegs (advanced vocational schools leading to admission to universities of applied science) and vocational high schools (leading to a general university entrance qualification) are the most relevant institutions when it comes to opening progression routes (Schindler, 2014). There is however a link with the dual system, too, since HE entrance qualifications in Germany are often used to access a high level apprenticeship placement, e.g. in banking, insurance or other attractive commercial occupations (Pilz, 2009).

Therefore, there is in fact a significant contribution of full-time VET to academisation, since it is possible to proceed from one stage in the VET school system (e.g. lower secondary school certificate) to the next one (e.g. intermediate secondary school certificate). In 1975, there were just some 5,155 graduates from vocational high schools in the federal state of Baden-Württemberg who obtained an Abitur, but in 2016, their number had risen to 18,646. Lower secondary school qualifications rose in a similar way, i.e. from nearly zero in 1975 to 3,806 in 2016 , while intermediate school qualifications have been declining since 1985 , from 13,063 to 9,705 due to a more open general secondary school system. ${ }^{4}$ However, academisation in this context does not necessarily mean setting up HQ as a key way of establishing permeability between vocational and higher education.

In Germany, the concept of 'hybridity' or 'hybrid' or 'double qualifications', respectively, is historically associated with the educational reform in the late 1960s and especially the 1970s. Inspired by the Social Democrats, one of the educational objectives emanating from the policy discourse was to integrate, 
both in organisational and curricular terms, VET and general education and to assign parity of esteem to culturally and pedagogically different educational pathways. The term 'Doppelqualifikationen' (double qualifications) was used particularly within the scope of this ambitious reform period, and it marks certainly one of the most fundamental debates in the area of vocational education theory in Germany, since it was linked to political objectives such as 'equality of opportunities', 'emancipation', 'democratisation' and, above all, a more stateorientated and school-based type of vocational learning (Zabeck, 2009, p. 659). The term itself was initially introduced by the Bund-Länder Commission for Educational Planning and Research Promotion (BLK) in 1974 (Zimmermann, 1982, p. 1). Subsequently, the expression 'Doppelqualifikation' became an important component of the educational debate in Germany (Bojanowski, 1996, p. 533; Kutscha, 2003).

When it comes to HQs today, we need to distinguish between those acquired in the dual system and those obtainable in a vocational full-time school, such as a Berufsfachschule or a Berufskolleg (vocational college in the following). HQs in the dual system are nearly non-existent in the German VET system (Deissinger et al., 2013b) - which is quite different from Switzerland, where the 'vocational Baccalaureat' has proved to become a popular amendment to occupational qualifications, a situation in this country which underlines the even more significant role the dual system plays in the Swiss society (Deissinger and Gonon, 2016). However, there is a (small) segment within the vocational fulltime school system in Germany which delivers HQ (Deissinger et al., 2013b). These institutions offer 'combinations of accredited general (academic) and vocational learning and attainment that formally qualify for entrance to higher education and the labour market' (Deissinger et al., 2013a, p. 8). HQs, especially in Germany, may be considered as a tool leading to a kind of generalisation of vocational education. Their relevance and importance is underlined by their function within the education system to open up vocational pathways into HE (though in most of the cases, only into the universities of applied science).

According to the official German training statistics (BiBB, 2017), schoolbased HQs are reported to be the second strongest category among schoolbased VET courses and qualifications behind the health sector, although the number of new entrants declined from some 29,000 in 2005 to some 22,000 in 2016 and eight out of 16 federal states do not offer HQs at all (BiBB, 2017, pp. 194, 198). One reason is that the vocational colleges (Berufskollegs) in BadenWürttemberg are now counted in another category, i.e. as 'schools leading to a higher school qualification'. This means that since 2008, the entrance qualification for HE has become the 'regular' qualification in these schools (Breuing et al., 2017; Deissinger and Breuing, 2016).

Against this background, the Berufskolleg $(\mathrm{BK})$ is an interesting example of school-based hybridity in Germany (Deissinger, 2007; Deissinger et al., 2006; Deissinger and Ruf, 2006). The Berufskolleg may be described as a secondary post-compulsory institution and an alternative to the later years of the grammar 
school in general education. It is open to students, normally aged between 16 and 18 , with a medium-level school-leaving qualification. Students enter either from the two-year vocational full-time school (Berufsfachschule), which takes up graduates from the lower secondary schools normally aged 15 or 16, or from the tenth year of the lower secondary schools (Werkrealschule) or from the two higher streams in the general education system (Gymnasium or Realschule). The vocational college is offered in a number of occupational fields but the largest proportion can be assigned to the commercial vocational college (Statistisches Landesamt Baden-Württemberg, 2017, p. 3). The commercial vocational college II (BK II), where the commercial assistant qualification is obtainable, is a good example for the polytechnic/university of applied sciences entrance qualification being combined with the assistant certificate. The BK II is based on the commercial vocational college I (BK I). Both the BK I and the BK II last one year each. Only students who have finished the BK I successfully (with adequate average grades) are allowed to attend the BK II. Until some ten years ago, students who had attended the elective mathematics class at the BK I could go for an entrance qualification for universities of applied sciences which then led to an HQ after completion of the BK II after attending even more additional subjects (for more details, see Deissinger et al., 2013b; Deissinger, 2007).

Within the scope of a comparative Leonardo research project on HQ in Germany, Austria, England and Denmark (Deissinger et al., 2013a), we found that 'academic aspirations' of students with an intermediate secondary school leaving certificate are best satisfied by the vocational college. Another very important motive of students for the attendance of a vocational college seems enhancing their own prospects of successfully entering apprenticeship training. Most graduates of this vocational full-time school traditionally aspire to take up subsequent vocational training in a company, i.e. through the dual system. On the other hand, the vocational college does not stand for leading young people to the achievement of a portable labour market relevant occupational qualification outside the dual system. This becomes clear when looking at the relevance of this function of the vocational college from the point of view of students (Deissinger et al., 2013a) The major reason certainly is that assistant qualifications are not acknowledged by companies, be it for subsequent training or for recognition of prior training. These empirical findings were confirmed by a smaller follow-up study, which even more came out with the fact that the most important motivation to attend a vocational college consists in the option to go to a university of applied science, closely followed by taking up a commercial apprenticeship in the dual system (Breuing et al., 2017).

Interview partners in the comparative Leonardo project argue that there is generally only 'modest interest' in HQs on the part of young people which could be a major obstacle for intensifying and widening HQ pathways within the dual system (this was especially an aspect put forward by teachers and headmasters). It is held that apprentices who prepare for HE while following a VET programme obviously face an additional workload, which can become 
too high a burden for apprentices. Another interesting argument points to the fact that apprentices normally are happy with their vocational perspective, especially when considering that continuing training can lead to a technician or a master craftsman qualification, and people can open up a business without passing through an academic pathway (Deissinger and Breuing, 2014). The strong position of the craft sector in the dual system (with a quarter of all apprentices) certainly explains this common understanding of occupational careers. Other arguments brought forward against $\mathrm{HQs}$ in the interviews were: the lack of information about $\mathrm{HQ}$, complaints about the reliability and transparency due to the major say of federal states in educational matters, the fear of rising public expenditure for VET due to HQ and the fear on the side of companies of losing trained employees after completion of their apprenticeships (for more details, see Deissinger et al., 2013b, p. 130).

HQs in Germany and their underlying educational programmes are on the one hand located in the vocational context, but on the other hand remain mostly separated from apprenticeship training (Frommberger, 2012, p. 187), which emphasises their 'scientific' character. Therefore, hybridity which is not linked to vocational training in a narrow sense, as is the case in Germany, has a stabilising impact on the dual system. Companies in Germany, at least in some major occupational fields, clearly prefer recruiting high quality school leavers from upper secondary education to other applicants for an apprenticeship. Graduates from the Berufskolleg in Baden-Württemberg now increasingly belong to this group, and they are perceived by employers as having a strong aspiration towards a company-based career (Deissinger and Ruf, 2006).

Reasons why HQs (still) have a comparatively inferior status in the German VET system (Deissinger et al., 2013b, p. 135) may be summarised as follows:

- The apprenticeship system is still the major and most accepted route into employment for non-academically inclined school leavers, and demand for apprentices on the side of employers is high.

- The school-based (full-time) VET system is seen as offering a number of opportunities for young people coming from the lower and middle tracks of the school system to proceed as high as to universities or (in even more cases) to the (formerly so-called) polytechnics or universities of applied sciences.

- Besides, there now exists an attractive 'dual system' on the academic level, namely the so-called 'vocational academies' or (as they now are called) 'universities of cooperative education' or 'dual universities' (Hippach-Schneider and Schneider, 2016; Deissinger, 2000; Deissinger and Ott, 2016, p. 275).

- Since the HE system is only coupled with school-based VET, and pathways from work to $\mathrm{HE}$ have been created recently to compensate for the missing links between the vocational and the academic sphere, there does not seem to exist a strong inclination on the side of politicians to establish more 'direct' progression routes. 


\section{Conclusion}

An article focussing on the differences between school-based VET in Australia and Germany identified some interesting differences between the two countries, but also noted some similarities (Deissinger et al., 2006). Both countries are facing common problems with the traditional apprenticeship model, which include the difficulty of attracting young people into specific occupations and also the reluctance of some employers to make the necessary investment in the system. In order to increase the labour market chances of young people and to address skill needs, both countries have installed initiatives at both federal and national levels to improve enrolments. In this context, one way of addressing the lack of apprentice places has been to offer vocational courses full-time although this alternative lacks legitimacy in the eyes of companies. While in Germany the apprenticeship model still functions as the core of the VET system, gaining vocational qualifications in schools or colleges is a widespread possibility in Anglophone countries, including the interesting option to start with VET in general education (Polesel and Clarke, 2011). In Germany, as we have explained in this chapter, full-time VET mostly aims at obtaining educational qualifications leading young people into progression routes as far as HE, whereas schoolbased training in Germany (which does not need to be full-time in a narrow sense of the word) only covers specific groups of occupations, such as health, child care/nursery nurses and the so-called 'assistant occupations'. The deeply entrenched nature of the dual system in Germany seems one of the reasons behind this system logic. One of the disadvantages of full-time VET certainly is its 'confusing' system architecture, with different formal responsibilities. However, some of the occupational courses are highly relevant for the German labour market. This is especially the case for services occupations in specific segments of the economy, such as health and child care. In terms of assessing the quality and relevance of the German full-time VET system, it seems necessary to point out this invaluable social and economic contribution of VET outside the dual system, together with those schools that make sure that young people do not get stuck in dead end educational roads. However, the fact that there is an ambivalence in the German VET system or, in other words, an ostensible multifunctionality also seems responsible for the relatively weak status of $\mathrm{HQ}$ in this country. It is above all the school-based VET system which still seems to oscillate between a clear qualification orientation and the role of schools to bridge the gap between VET and HE.

\section{Notes}

1 In 2016, nearly 300,000 young people had to enter a 'measure' in the transition system. Some of these measures traditionally are offered by vocational schools, including the first year of courses in Berufsfachschulen (not fully qualifying) or the Vocational Preparation Year (BMBF, 2017, p. 45; Statistisches Bundesamt, 2017b, p. 24f.).

2 Between 2005 and 2016, the number of entrants fell from some 11,500 down to some 4,500 young people (BiBB, 2017, p. 194f.). 
3 See www.gesetze-im-internet.de/krpfl__2004/BJNR144210003.html (Accessed: 12/02/18).

4 See www.statistik-bw.de/BildungKultur/SchulenAllgem/abgaenger_mehrjaehrig.jsp?path=/ BildungKultur/SchulenBerufl/ (Accessed: 13/02/18).

\section{References}

Bohl, T. and Meissner, S. (2013) Expertise Gemeinschaftsschule. Forschungsergebnisse und Handlungsempfehlungen für Baden-Württemberg, Weinheim, Beltz.

Bojanowski, A. (1996) 'Modelle zur Doppelqualifikation', in Dedering, H. (ed.), Handbuch zur arbeitsorientietten Bildung, München, Oldenbourg, pp. 533-559.

Bonse-Rohmann, M. (2015) 'Strukturen, Orientierungen und neuere Entwicklungen der Lehrerinnen-und Lehrerbildung in den beruflichen Fachrichtungen Gesundheit und Pflege', in Pundt, J. and Kälble, K. (eds.), Gesundheitsberufe und gesundheitsberufliche Bildungskonzepte, Bremen, Apollon University Press, pp. 165-197.

Breuing, K., Deissinger, Th., and Heck, J. (2017) 'Subjektive Theorien von Schüler/-innen des Kaufmännischen Berufskollegs mit Übungsfirma (BK-ÜFA) in Baden-Württemberg mit Blick auf Kompetenzerleben und berufliche Aspirationen', Wirtschaft und Erziehung, vol. 69 , no. 2 , pp. $63-68$.

Bundesinstitut für Berufsbildung (BiBB) (2017) Datenreport zum Berufsbildungsbericht 2017, Bonn, BiBB.

Bundesministerium für Bildung und Forschung (BMBF) (2017) Berufsbildungsbericht 2017, Bonn, BMBF.

Deissinger, Th. and Ott, M. (2016) 'Tertiarisation of vocational education and training and its implications: Problems and issues in Germany and France', in Bohlinger, S., Dang, T. K. A., and Glatt, M. (eds.), Education Policy: Mapping the Landscape and Scope, Frankfurt a.M., Peter Lang, pp. 267-296.

Deissinger, Th. (1996) 'Germany's vocational training act: Its function as an instrument of quality control within a tradition-based vocational training system', Oxford Review of Education, vol. 22, no. 3, pp. 317-336.

Deissinger, Th. (1998) Benuflichkeit als "organisierendes Prinzip" der deutschen Berufsausbildung, Markt Schwaben, Eusl.

Deissinger, Th. (2000) 'The German "Philosophy" of linking academic and work-based learning in higher education: The case of the "vocational academies"', Journal of Vocational Education and Training, vol. 52, no. 4, pp. 609-630.

Deissinger, Th. (2007) "'Making schools practical": Practice firms and their function in the full-time vocational school system in Germany', Education and Training, vol. 49, no. 5, pp. 364-379.

Deissinger, Th. (2010) 'Dual System', in Peterson, P., Tierney, R., Baker, E., and McGaw, B. (eds.), International Encyclopedia of Education, 3rd Edition, vol. 8, Oxford, Elsevier, pp. $448-454$.

Deissinger, Th. and Breuing, K. (2014) 'Recruitment of skilled employees and workforce development in Germany: Practices, challenges and strategies for the future', in Short, T. and Harris, R. (eds.), Workforce Development: Strategies and Practices, Singapore, Springer, pp. 281-301.

Deissinger, Th. and Breuing, K. (2016) 'Übungsfirmen an beruflichen Schulen in Deutschland am Beispiel des Berufskollegs Baden-Württemberg: ihr Beitrag zur Praxisorientierung', in Fortmüller, R. (ed.), Entrepreneurship Erziehung und Gründungsberatung - Beiträge zur Entrepreneurship Erziehung und Gründungsberatung aus ukrainischer, nussischer und europäischer Perspektive, Wien, Manz, pp. 51-60. 
Deissinger, Th. and Gonon, Ph. (2016) 'Stakeholders in the German and Swiss vocational educational and training system: Their role in innovating apprenticeships against the background of academisation', Education and Training, vol. 58, no. 6, pp. 568-577.

Deissinger, Th. and Ruf, M. (2006) Übungsfirmen am Kaufmännischen Berufskolleg in BadenWürttemberg. Praxisorientierung vollzeitschulischer Berufsbildung zwischen Anspruch und Wirklichkeit, Paderborn, Eusl.

Deissinger, Th., Smith, E., and Pickersgill, R. (2006) 'Models of full-time and part-time vocational training for school-leavers: A comparison between Germany and Australia', International Journal of Training Research, vol. 4, no. 1, pp. 30-50.

Deissinger, Th. et al. (2013a) Hybrid Qualifications: Structures and Problems in the Context of European VET Policy, Bern, Peter Lang.

Deissinger, Th. et al. (2013b) 'Progression from VET into higher education via hybrid qualifications in Germany: Context-policy-problem issues', in Deißinger, Th., Aff, J., Fuller, A., and Jorgensen, C. H. (eds.), Hybrid Qualifications: Structures and Problems in the Context of European VET Policy, Bern, Peter Lang, pp. 111-145.

Dobischat, R., Milolaza, A., and Stender, A. (2009) 'Vollzeitschulische Berufsbildung - eine gleichwertige Alternative zur dualen Berufsausbildung', in Zimmer, G. and Dehnbostel, P. (eds.), Berufsausbildung in der Entwicklung - Positionen und Leitlinien, Bielefeld, W. Bertelsmann, pp. 127-151.

Federal Ministry of Education and Research (2017) Report on Vocational Education and Training, Bonn, BMBF.

Feller, G. (2002) 'Leistungen und Defizite der Berufsfachschule als Bildungsgang mit Berufsabschluss', in Wingens, M. and Sackmann, R. (eds.), Bildung und Beruf. Ausbildung und berufstruktureller Wandel in der Wissensgesellschaft, Weinheim, Juventa, pp. 139-157.

Feller, G. (2004) 'Ausbildungen an Berufsfachschulen - Entwicklungen, Defizite und Chancen', Berufsbildung in Wissenschaft und Praxis, vol. 33, no. 4, pp. 48-52.

Friese, M. (2017) 'Care work. Eckpunkte der Professionalisierung und Qualitätsentwicklung in personenbezogenen Dienstleistungsberufen', in Weyland, U. and Reiber, K. (eds.), Entwicklungen und Perspektiven in den Gesundheitsberufen - aktuelle Handlungs-und Forschungsfelder, Bielefeld, W. Bertelsmann, pp. 29-49.

Frommberger, D. (2012) 'Von der Berufsbildung in die Hochschulbildung (Dritter Bildungsweg). Eine berufs-und wirtschaftspädagogische Einordnung unter besonderer Berücksichtigung aktueller Rahmenwerke zur Förderung von Übergängen und Durchlässigkeit', Zeitschrift für Berufs-und Wirtschaftspädagogik, vol. 108, no. 2, pp. 169-193.

Greinert, W.-D. (1994) The "German System" of Vocational Training: History, Organization, Prospects, Baden-Baden, Nomos.

Harris, R., Sumner, R., and Rainey, L. (2005) Student Traffic: Two-Way Movement between Vocational Education and Training and Higher Education, Adelaide, NCVER.

Hippach-Schneider, U. and Schneider, V. (2016) Tertiary Vocational Education in Europe: Examples from Six Education Systems, Bonn, Federal Institute for Vocational Education and Training.

Jacob, M. and Solga, H. (2015) 'Germany's vocational education and training system in transformation: Changes in the participation of low-and high-achieving youth over time', European Sociological Review, vol. 31, pp. 161-171.

Kell, A. (2006) 'Organisation, Recht und Finanzierung der Berufsbildung', in Arnold, R. and Lipsmeier, A. (eds.), Handbuch der Berufsbildung, Wiesbaden, VS Verlag, pp. 453-484.

Kutscha, G. (2003) 'Zum Verhältnis von allgemeiner und beruflicher Bildung im Kontext bildungstheoretischer Reformkonzepte - Rückblick und Perspektiven', Zeitschrift für Berufsund Wirtschaftspädagogik, vol. 99, no. 3, pp. 328-349. 
Luhmann, N. and Schorr, K.-E. (1979) Reflexionsprobleme im Erziehungssystem, Stuttgart, Klett-Cotta.

Ministerium für Kultus, Jugend und Sport Baden-Württemberg (2014) Bildungswege in Baden-Württemberg, Stuttgart, MKjS.

Neugebauer, M. (2010) 'Bildungsungleichheit und Grundschulempfehlung beim Übergang auf das Gymnasium: Eine Dekomposition primärer und sekundärer Herkunftseffekte', Zeitschrift für Soziologie, vol. 39, no. 3, pp. 202-214.

Noah, H. J. and Eckstein, M. A. (1988) 'Business and industry involvement with education in Britain, France and Germany', in Lauglo, J. and Lillis, K. (eds.), Vocationalizing Education: An International Perspective, Oxford, Pergamon Press, pp. 45-68.

Pilz, M. (2009) 'Why abiturienten do an apprenticeship before going to university: The role of "double qualifications" in Germany', Oxford Review of Education, vol. 35, no. 2, pp. 187-204.

Polesel, J. and Clarke, K. (2011) 'The marginalisation of VET in an Australian secondary school', Journal of Vocational Education and Training, vol. 63, no. 4, pp. 525-538.

Raggatt, P. (1988) 'Quality control in the dual system of West Germany', Oxford Review of Education, vol. 14, no. 2, pp. 163-186.

Schindler, S. (2014) Wege zur Studienberechtigung - Wege ins Studium? Eine Analyse sozialer Inklusions-und Ablenkungsprozesse, Wiesbaden, VS Verlag.

Schmidt, C. (2011) Krisensymptom Übergangssystem: Die nachlassende soziale Inklusionsfähigkeit beruflicher Bildung, Bielefeld, W. Bertelsmann.

Seeber, S. and Michaelis, C. (2015) 'Zur Entwicklung des Schulberufssystems: eine Analyse im Kontext demographischer Veränderungen und arbeitsmarktbezogener Herausforderungen', Recht der Jugend und des Bildungswesers, vol. 63, no. 3, pp. 271-290.

Statistisches Bundesamt (2017a) Bildung und Kultur. Berufliche Bildung, Fachserie 11, Reihe 3, Wiesbaden.

Statistisches Bundesamt (2017b) Bildung und Kultur. Berufliche Schulen, Schuljahr 2015/2016, Fachserie 11, Reihe 2, Wiesbaden.

Statistisches Bundesamt (2017c) Bildung und Kultur. Schnellmeldungsergebnisse zu Studienberechtigten der allgemeinbildenden und beruflichen Schulen - vorläufige Ergebnisse, Abgangsjahr 2016, Fachserie 11, Reihe 1 und 2, Wiesbaden.

Statistisches Landesamt Baden-Württemberg (2017) Statistik aktuell, Stuttgart. Available at www.statistik-bw.de (Accessed 24 March 2018).

Zabeck, J. (1985) 'Berufliche Bildung', in Görres-Gesellschaft (ed.), Staatslexikon Recht Wirtschaft - Gesellschaft, 7th Edition, Freiburg, Herder, pp. 669-683.

Zabeck, J. (2009) Geschichte der Berufserziehung und ihrer Theorie, Paderborn, Eusl.

Zimmermann, H. (1982) Doppeltqualifizierende Bildungsgänge. Gesellschaftliche Ursachen für die politische Thematisierung als Reformvorhaben: Probleme, Formen und Perspektiven der Realisierung, Weinheim, Beltz.

Zöller, M. (2012) 'Qualifizierungswege in den Gesundheitsberufen und aktuelle Herausforderungen', Berufsbildung in Wissenschaft und Praxis, vol. 41, no. 6, pp. 6-10. 